\title{
The Potential of Food Irradiation: Benefits and Limitations
}

\author{
Hossein Ahari Mostafavi $1^{*}$, \\ Seyed Mahyar Mirmajlessi ${ }^{2}$ and Hadi Fathollahi ${ }^{1}$ \\ ${ }^{1}$ Nuclear Science and Technology Research Institute, Agricultural, \\ Medical and Industrial Research School, Karaj, \\ ${ }^{2}$ Dept. Plant Pathology, College of Agriculture, \\ Tarbiat Modares University, Tehran,
}

Iran

\section{Introduction}

Preservation of food has been a major anxiety of man over the centuries. Contamination with microorganisms and pests causes considerable losses of foods during storage, transportation and marketing (15\% for cereals, $20 \%$ for fish and dairy products and up to $40 \%$ for fruits and vegetables). Particularly, pathogenic bacteria are an important cause of human suffering and one of the most significant public health problems all over the world. The World Health Organization (WHO) stated, the infectious and parasitic diseases represented the most frequent cause of death worldwide (35\%), the majority of which happened in developing countries in 1992 (Loaharanu, 1994). Numerous processing techniques have been developed to control food spoilage and raise safety. The traditional methods have been supplemented with pasteurization (by heat), canning, freezing, refrigeration and chemical preservatives (Agrios, 2005). Another technology that can be added to this list is irradiation. Food irradiation is the process of exposing amount of energy in the form of speed particles or rays for improving food safety, eliminating and reducing organisms that destroy the food products. This is a very mild treatment, because a radiation dose of $1 \mathrm{kGy}$ represents the absorption of just enough energy to increase the temperature of the product by $0.36^{\circ} \mathrm{C}$. It means that, heating, drying and cooking cause higher nutritional losses. Moreover, heterocyclic ring compounds and carcinogenic aromatic produced during thermal processing of food at high temperatures were not identified in irradiated foods (Tomlins, 2008). More than one century of research has gone into the understanding of the effective use of irradiation as a safety method. It has been repeatedly considered and judged suitable on available evidence. The international bodies including the Food and Agriculture Organization (FAO), the International Atomic Energy Agency (IAEA), WHO and Codex Alimentarius Commission (CAC) investigate projects on food irradiation to verify the safety and quality of different irradiated products. It has shown that irradiation used on alone or in combination with other methods could improve the microbiological safety and extend shelf-

${ }^{*}$ Corresponding Author 
life (IAEA, 2009). Furthermore, people are very confused to distinguish irradiated foods from radioactive foods. At no time during the irradiation process does the food come into contact with the radiation source and, it is not possible to induce radioactivity in the food by using gamma rays or electron beams up to $10 \mathrm{MeV}$ (Farkas, 2004). The differences in chemical and physical structure of organisms, environmental factors, moisture content, temperature during irradiation, presence or absence of oxygen and in their ability to recover from the radiation injury cause the distinctions in their sensitivity to radiation. According to long-term animal feeding studies, radiation-pasteurized or sterilized foods are safe and nutritious also for humans (Thayer \& Boyd, 1999). Irradiation is used for a variety of reasons, such as disinfesting food, reducing or eliminating food borne pathogens, shelf life extending and may serve as a quarantine treatment for many fruits, vegetables, nuts, cut flowers and animal origin products to facilitating international trade of foods (Marcotte, 2005). But, not all foods are appropriate for irradiation. For instance, some fruits (such as cucumbers, grapes, and some tomatoes) are sensitive to radiation. Nowadays, over 60 countries use irradiation for one or more food products. But, the misconceptions and irrational fear of nuclear technologies mostly caused the lack of acceptance of food irradiation. It should be noted that if irradiated products offer clear advantages, and the science-based information on the process is readily available, consumers would be ready to accept more irradiated products.

\section{Effects of lonizing radiation}

Irradiation can be effect direct, caused by reactive oxygen-centred $(\bullet \mathrm{OH})$ radicals originating from the radiolysis of water or indirect on organisms and food products. An indirect effect (the damage to the nucleic acids) occurs when radiation ionizes a neighboring molecule, which in turn reacts with the genetic material. Since, water is a major component of most foods and microbes; it is often ends up producing a lethal product (Hallman, 2001). The optimum dose is a balance between that what is needed and that what can be tolerated by the products (European Food Safety Authority [EFSA], 2011).

\subsection{Effects on bio-organisms (microorganisms and insects) and viruses}

The biological effects caused by irradiation are primarily the result of disruption of the DNA or RNA in the nuclei of cells. Since, the DNA is much larger than the other molecular structures and very long ladder twisted into a double helix in a cell, if it becomes injured, by either primary ionizing or through secondary free radical attack, the induced biological and chemical changes can prevent replication and destroy cells (Scott Smith \& Suresh, 2004; The Institute of Food Science and Technology [IFST], 2006). Therefore microorganisms, insect gametes, and plant meristems are prevented from their reproduction, which consequently results in various preservative effects as a function of the absorbed radiation dose (Scott Smith \& Suresh, 2004).

Since, the size of the DNA molecule generally increases with the complexity of an organism, viruses are more radiation resistant than other organisms (Koopmans \& Duizer, 2004). Viruses do not grow in food directly, but can contaminate host bacteria (Deeley, 2002). Poliomyelitis viruses and infectious hepatitis can be transmitted by means of infected raw milk and shellfish (DeWit et al., 2003; Frankhauser et al., 2002). More studies showed that 
the combination of irradiation with heating can be used successfully to inactivation of viruses (Koopmans \& Duizer, 2004).

The spore-forming bacteria are resistant to irradiation and other treatments. Doses used below $10 \mathrm{kGy}$ may only give a $2-3 \log _{10}$ reduction in spore numbers, and this is not sufficient to foods shelf-life (Patterson et al., 2006). Yeasts are more radiation resistance than molds and vegetative bacteria. So, they are important in the spoilage of irradiated meat products (such as sausages) stored at refrigeration (Patterson et al., 2006; Scott Smith \& Suresh, 2004).

Insects, mites and other such pests are higher level, multicellular organisms responsible for considerable loss of fresh produce and grains. Also, they can provide as vectors for carrying pathogenic bacteria and parasites (Ahari et al., 2010). The best control of insects in agricultural products can be achieved by using fumigants (such as ethylene bromide). But, the use of these pesticides has been forbidden or severely restricted in most countries (World Health Organization, 2005). Consequently, radiation has been suggested as an alternative to them. Irradiation as direct control is one aimed primarily at reducing insects population. For the first time in the early 1957s irradiation as a commercial insect control technique was applied to spices in the Federal Republic of Germany (Diehl, 1995). Basis of practical experience, the necessary radiation dose to pests control according to different growth stages is in the range of 100-1000 Gy. A dose level of $250 \mathrm{~Gy}$ can be used for quarantine treatment of fruit flies, while a dose of 500-1000 Gy can control all stages of other pests (Landgraf, et al., 2006; Marcotte, 2005). Indirect control, on the other hand is the sterile insect technique (SIT). The principle of the technique is to introduce sterility by rearing great numbers of the pest and release them into the target area. When the released males mate with wild females, the females generate no viable offspring. With a constant releasing rate of sterile males over several generations, this results a rapid decline in the overall population. The sterilization process (in this method) is important in determining the quality of the released pests and their ability to compete with the wild population. SIT has been used against a number of pest species like as Mediterranean fruit fly Ceratitis capitata (Wiedemann), melon fly Bactrocera cucurbitae (Coquilett), pink bollworm Pectinophora gossypiella (Saunders), codling moth Cydia pomonella (L.) and tsetse fly Glossina austeni Newstead (Hendrichs et al. 2005; Klassen \& Curtis, 2005).

\subsection{Mutagenic and toxin production effects}

Mutation in micro-organisms is a well known event. So, selection of spontaneous mutants and production of mutant strains by various mutagenic agents are practiced for scientific and industrial purposes. Ionizing radiation is able to induce mutations, as a number of physical or chemical antimicrobial agents. Some evidences showed that the pathogenicity of infectious organisms is diminished by irradiation (EFSA, 2011). Studies on transcriptional changes of S. Typhimurium and Vibrio spp., showed that, the expression of the virulence genes in Salmonella irradiated mutants was reduced, and expression of toxin genes of Vibrio irradiated mutants did not increase, compared with non-irradiated counterparts (Lim et al., 2007). The wholesomeness (lack of teratogenicity, mutagenicity, and toxicity) of irradiated products has been studied expansively (IAEA, 2009). Multigenerational feeding studies did not show any confirmation of toxicological effects in mammals due to intake of irradiated foods. It means, multigenerational studies with animals have showed that the nutritive value remains essentially unchanged and that the ingestion of irradiated foods is completely 
safe (Thayer \& Boyd, 1999; IAEA, 2009). Food irradiation has not provided any evidence of increased threat of mycotoxin formation in irradiated food. Therefore these do not show any specific hazard in relation to mycotoxin production (Kottapalli et al., 2006).

\subsection{Radiation resistance}

Radiation resistance in organisms is different. For instance, Alternaria sp. and Fusarium sp. are more resistant than the penicillium sp. and Aspergillus sp. Fusarium and Alternaria Spores are multicellular. If only one cell survives, the spore may still have the ability to germinate. So, these spores are more radiation resistant (Patterson et al., 2006). The effect of repeated doses of $\gamma$-radiation indicated a progressive increase of the radiation resistance of the organisms when exposed at sublethal dose. But, under industrial conditions, no situation is conceivable whereby a population of organisms would be repeatedly resuscitated after sublethal irradiation (Levanduski \& Jaczynski, 2008). Some studies on food irradiation facilities and many other radiation-emitting sources showed no evidence for increased occurrence of resistant strains in the environment of these facilities (Scientific Committee on Food [SCF], 2003).

\subsection{Selective effects on the microbial flora}

Vegetative food pathogens and non pathogenic microorganisms are sensitive to radiation. The medium-dose irradiation processes reduce their populations by several $\log 10$ cycles. The possibility that decrease of the competitive microflora could assist growth of food pathogens after irradiation was studied. The study did not show any significant difference in the bacterial growth in irradiated food compared to non-irradiated one. Results indicated that, the absence of the spoilage microflora in food did not provide a competitive advantage to the bacterial growth (Prendergast et al., 2009).

\section{Effects on food products}

Ionizing radiation produces chemical changes by primary and secondary radiolysis effects. The effect of chemical reactions depends on the absorbed dose, dose rate and facility type, presence or absence of oxygen and temperature. Generally, most food micronutrients (mainly water-soluble and fat-soluble vitamins) and macronutrients (carbohydrates, proteins, and lipids) are not affected by $10 \mathrm{kGy}$-range -range ionizing dose with regard to their nutrient contents. But, with radiation doses above $10 \mathrm{kGy}$, the properties of fibrous carbohydrates can be degraded structurally and lipids can become somewhat rancid (Miller, 2005; Brewer, 2009). The physical status of food (frozen or fresh, solid, liquid or powder) and also its composition influence the reactions induced by the radiation (IAEA, 2009). Direct absorption of energy by the irradiated food can produce chemical changes via primary and secondary indirect radiolysis effects. Irradiation effects water molecule to free an electron producing $\mathrm{HO}+$. This product reacts with other water molecules to create a quantity of compounds, including hydrogen and hydroxyl radicals $(\mathrm{OH} \bullet$ ), hydrogen peroxide $(\mathrm{HO})$, molecular hydrogen and oxygen. Because the hydroxyl radical is an oxidizing agent, and the hydrated electron is a reducing agent, free radical attack can be expected to cause oxidizing and reducing reactions in food (Black \& Jaczynski, 2008; Calucci 
2003). Chemical reactions and the products generated from major food components like fat, proteins, carbohydrates and vitamins are described as fallow:

\subsection{Carbohydrates}

The use of gamma-irradiation (up to $6.2 \mathrm{kGy} / \mathrm{h}$ ) to starches from maize, wheat, rice or potato, induced the aldehydes such as malonaldehyde, formaldehyde, and acetaldehyde, formic acid and hydrogen peroxide as main radiolytic products (Stefanova et al., 2010). Recent studies showed that, gamma irradiated solutions of fructose, glucose, sucrose and starch (at $3 \mathrm{kGy}$ at $5^{\circ} \mathrm{C}$ ) produced malonaldehyde, But, the accumulation of aldehydes formed after irradiation of fruit juices decreased by reducing the presence of oxygen and using low temperature (Fan, 2003; Fan \& Thayer, 2002). In general, irradiation modifies Mono and polysaccharides, but thermal treatment can produce more modifications (Fan, 2005).

\subsection{Proteins}

The study showed that, the irradiation of proteins could produce chemical reactions depend on the protein structure, state (native or denatured), physical status, amino acid composition, the presence of other substances and the radiation treatment. The most important changes include dissociation, aggregation, cross-linking and oxidation. For example gamma irradiation of hazelnuts at $10 \mathrm{kGy}$ induced protein aggregation and denaturation (Dogan et al., 2007). Also, the reported decrease in pectinase activity (the most sensitive enzyme to irradiation) at $20 \mathrm{kGy}$ was in the range $20 \%$ to $50 \%$, (Duliu et al., 2004). Indeed, low and medium doses induce only a small breakdown of food proteins into lower molecular weight protein parts and amino acids. As a result, experiments indicated that such treatments cause less chemical reactions than steam heat sterilization (Fan \& Sommers, 2006).

\subsection{Lipids}

Due to free radicals formed during irradiation, it has been proven to increase lipid oxidation (Stewart, 2009). The chemical effects are more relevant in foods with larger fat content, physical status (liquid or solid), presence of antioxidants, environmental conditions (light, heat, oxygen, moisture, $\mathrm{pH}$ ), the irradiation treatment, type of storage (vacuum, modified atmosphere, etc.), storage conditions (time, temperature, light, etc.) and high unsaturated fatty acids content (EFSA, 2011). The use of low temperatures, the presence of oxygen, antioxidants and suitable packaging type showed a great capacity to minimize lipid oxidation (Stefanova et al., 2010). Phytosterols (include sterols and stanols), which are naturally present in cereals, nuts, seeds, fruits and vegetables have a structure similar to cholesterol. These compounds can be oxidized by standard heating treatments and also by irradiation and produce oxyphytosterols (Da Trindade et al., 2009; Johnsson \& Dutta, 2006).

\subsection{Vitamins}

The primary effects of radiation on vitamins at low and medium doses are not considerable. But, the combination of free radicals produced through irradiation with antioxidant vitamins can lose some of their influence (Stefanova et al., 2010). In the case of water soluble vitamins, Thiamine is the most sensitive and significant losses can occur in irradiated meats. 
Irradiation of chicken meals with $1 \mathrm{kGy}$ resulted in a 16\% decrease in thiamine compared with non-irradiated meals (Stewart, 2009). Mitchell et al. (1992) showed that, irradiation of capsicums (green and red), cucumbers, apples, lemons, lychees, mandarins, mangoes, nectarines, papayas, peaches, persimmons, and zucchinis at doses of 75 - 300 Gy can induce small changes in some parameters, such as vitamin $C$ and dehydroascorbic acid after 3 to 4 weeks of storage at $1-7^{\circ} \mathrm{C}$. However, storage effects were higher than irradiation effects. Dionísio et al. (2009) demonstrated that, Strawberries (Shasta variety, Fragaria sp.) submitted to 1.0-2.0 kGy doses did not show any significant decrease in vitamin C levels during two and 11 days of storage at $5^{\circ} \mathrm{C}$. Folic acid levels decreased $20-30 \%$ following irradiation with a dose of $2 \mathrm{kGy}$, and no additional decrease was observed at the higher dose of $4 \mathrm{kGy}$ (Galan et al., 2010). After gamma irradiation at a dose of $10 \mathrm{kGy}$, significant losses (10 to $34 \%$ ) of total ascorbate and carotenoids (about 40-60\%) have been reported for cinnamon, nutmeg, black pepper, oregano, parsley, rosemary, bird pepper, and sage. (Calucci et al., 2003). No transforms have been showed for Riboflavin, vitamin B6, vitamin B12 and niacin after gamma irradiation with up to $5 \mathrm{kGy}$ in wheat, maize, mung beans and chick peas (Kilcast, 1994). The different sensitivity levels of food vitamins to processing are shown in Table 1. More studies showed that after high dose gamma-irradiation, E-beam irradiation or heat sterilization treatments, vitamin losses in the food are within similar ranges in all cases (Galan et al., 2010; EFSA, 2011).

\begin{tabular}{lll}
\hline Highly sensitive & Moderatly sentitive & Little sensitive \\
\hline A (retinol) & b-carotene & Folic Acid \\
B1(thiamin) & K (in meat) & Pantothenic Acid \\
C (ascorbic acid + dehydro- & & B2 (Riboflavin) \\
ascorbic) & & B3 (Niacin) \\
E (a-tocopherol) & B6 (Pyridoxine) \\
& B10 (Biotin) \\
& B12 (Cobalamin) \\
& Choline \\
& D \\
& K (in vegetables) \\
\hline
\end{tabular}

Table 1. Different sensitivity levels of food vitamins to processing (Dionísio et al., 2009)

\subsection{Inorganic salts}

Primary radicals are moderately uncreative towards inorganic anions, excepting for nitrates which are reduced by solvated electrons to nitrites. In frozen muscle foods this is considered to be a rare event because of the competition for electrons by the other matrix ingredients (SCF, 2003).

In summary, carbohydrates, proteins, lipids (the macronutrients), vitamins and inorganic salts are not significantly affected by low and medium range doses according to their nutrient content and digestibility. Indeed, traditional food preservation methods (heating, drying and cooking) may cause upper nutritional losses. 


\section{Main objectives and limitations of food irradiation}

The type of food being processed and the desired effects determine the radiation dose used in food processing. The examples of recommended dose ranges and the main purposes of food irradiation for different purposes are listed in Table 2.

\begin{tabular}{lc}
\hline \multicolumn{1}{c}{ Purpose and effects } & $\begin{array}{c}\text { Dose } \\
\text { range } \\
\text { (kGy) }\end{array}$ \\
\hline $\begin{array}{l}\text { Inhibition of sprouting of stored tubers, roots and bulbs } \\
\text { Prevention of post-harvest losses by destruction of insects in stored cereals, } \\
\text { fresh and dried fruits, nuts, oilseeds and pulses, or phytosanitary } \\
\text { (quarantine) treatment for insect pests infesting fresh fruits and vegetables }\end{array}$ & $0.05-15$ \\
$\begin{array}{l}\text { Delay of ripening of fruits } \\
\text { Shelf-life extension of fruit and vegetables, meat, poultry, fish and ready } \\
\text { meals by reduction of micro-organisms that cause spoilage }\end{array}$ & $0.15-1$ \\
$\begin{array}{l}\text { Inactivation/destruction of various food-borne parasites } \\
\text { Prevention of food-borne illness by destruction of non-sporeforming } \\
\text { pathogenic bacteria (e.g. Salmonella, Campylobacter, Listeria) in fresh or } \\
\text { frozen foods }\end{array}$ & $0.5-3$ \\
$\begin{array}{l}\text { Shorten drying and cooking times of vegetables and fruits } \\
\text { Reduction in viable counts of microorganisms in spices and other dry } \\
\text { ingredients to minimize contamination of food to which the ingredients are } \\
\text { added }\end{array}$ & $0.3-6$ \\
$\begin{array}{l}\text { Production of microbiologically shelf-stable, vacuum-packaged meat, } \\
\text { poultry and ready-to-eat meals by heat-inactivating of their tissue-enzymes } \\
\text { and sterilizing them by irradiation in deep-frozen state }\end{array}$ & up to 50 \\
\hline *The maximum doses reported are intended for good irradiation practice and not for \\
$\begin{array}{l}\text { consumer safety purposes. } \\
\text { Applications up to 1 kGy, between 1 and 10 kGy, and higher than 10 KGy are referred to } \\
\text { as low-dose, medium-dose, and high-dose irradiation, respectively. }\end{array}$ \\
$\begin{array}{l}\text { Table 2. Main purposes of food irradiation and examples of recommended dose ranges } \\
\text { (EFSA, 2011). }\end{array}$
\end{tabular}

\subsection{Fruits and vegetables}

Several food-borne outbreaks have reported in fruit products such as fresh fruit salads and non pasteurized fruit juices (Lynch et al., 2009; Vojdani et al., 2008). Applicable doses on fruit products are limited by their impact on quality (Arvanitoyannis et al., 2009). Irradiation should anticipate 2 to more than $5 \log 10$ reduction of pathogenic (non spore forming bacteria), in some fresh and many processed fruits. But, less than $1.5 \log 10$ reductions should be expected for the most radiation sensitive fruits. In many cases, surface decontamination of fruits, pre-washed and packaged vegetables and ready-to-eat fresh processed products with chemical agents should be less efficient (by at most $2 \log 10$ reduction) than food irradiation (Arvanitoyannis et al., 2009). Most studies indicated that, the irradiation of fresh fruits led to a reduction in firmness. The maximum doses which can be applied on fruits and vegetables range between 1 and $2 \mathrm{kGy}$. However these maximum 
values depend on the type of products and might modify with new, resistant cultivars (Zhu, et al., 2009). For example, some salad vegetables could resist up to $4000 \mathrm{~Gy}$ without physical-chemical damages and considerable quality loss (Nunes et al., 2008) whereas, for some products, such as lettuce leaves and apple fruit (Gala and Fuji variety) radiation doses should not exceed 600 Gy (Dionísio et al., 2009; Niemira et al., 2002).

Some products have a very short shelf-life. For instance, within a day at $10^{\circ} \mathrm{C}$ the cap of mushroom opens, the stem elongates, and the gills darken. Research showed that mushroom irradiated at a dose of 1.5 to $2.0 \mathrm{kGy}$ soon after harvest had a shelf-life at $5^{\circ} \mathrm{C}$ of 11 days, and at $10^{\circ} \mathrm{C}$, of 7 days. Most investigations show that sensory quality of mushroom is unaffected by irradiation (IAEA, 2001). For powdered dehydrated vegetables higher treatments (3-5 kGy) were suggested (Dong-Ho et al., 2002). Treatments for instance calcium chloride could decrease the effect of irradiation on fruit firmness (Prakash et al., 2007). Also, D10 values for various Salmonella strains in orange juice were between 0.6 and $0.8 \mathrm{KGy}$ (Niemira \& Lonczynski, 2006). Since, viruses are more resistant to irradiation, the doses applicable to most fresh fruits and fruit products will be of limited efficacy (Koopmans \& Duizer, 2004).

\subsection{Cereal products}

Cereals, grains and dry legume seeds are usually consumed after a wide range of processing. Operations and irradiation (tested at doses between 1 and $10 \mathrm{kGy}$ ) can modify the quality and technological properties of cereals and cereal products positively or negatively (Lynch et al., 2009). Irradiation (as a pest control method) has some advantages include the absence of undesirable residues in the foods treated, no resistance development by pest insects and few significant changes in the physicochemical properties or the nutritive value of the treated products (Ahmed, 2001). Several studies had been done on the use of irradiation (as an approved method) to control stored-product pests in wheat, flour and dry legume seeds in many countries (Azelmat et al., 2005; Boshra \& Mikhaiel, 2006). Lower radiation doses can not cause immediate death of adults but can prevent an increase in pest populations through lethal effects on the immature stages of adults (Hosseinzadeh \& Shayesteh, 2011). The major safety concern since 1986 for cereals has been mycotoxin producing fungi. Some recent studies have shown irradiation up to $10 \mathrm{kGy}$ can reduce the colonization of cereals with mycotoxin producing fungi. For instance, 6 to $8 \mathrm{kGy}$ reduces the risk of mycotoxin accumulation during barley germination for malt production. However, such doses have no impact on toxins already present in the cereals (Kottapalli et al., 2006).

\subsection{Tubers}

Starchy tubers are an important source of starch used in the food industry. In order to provide consumers a year-round supply of various sprouting foods, storage durations of up to several months are often necessary. Sprouting can be inhibited by refrigeration and the application of various chemicals. But, refrigeration is expensive and particularly in the tropical and subtropical regions of the world. Whereas, the chemical treatments are relatively inexpensive and efficient, they do leave residues and many countries have banned their usage for health reasons (Ahari et al., 2010). In such instances, irradiation can be recommended as a reasonable alternative. The first use of food irradiation for a fresh 
commodity was on potatoes in Canada in 1965 to inhibit sprouting (Diehl, 1995). Starchy tubers are also normally consumed after heat treatments and have rarely been the cause of food borne disease. Starch can be a significant source of spores of pathogenic bacteria such as Bacillus cereus in processed foods (Guinebretiere et al., 2003; Guinebretiere \& NguyenThe, 2003). Irradiation can be recommended for sprouting inhibition (in the range of $50-200$ Gy) and disinfestations purposes (at doses similar to those used for other dry foods) in sprouting foods such as potatoes, garlic, onions and yams (Marcotte, 2005).

\subsection{Spices and condiments}

Spices and condiments naturally, contain a great number of microorganisms. They often originate in developing countries where harvest and storage conditions are insufficiently controlled. Thus, Spices and condiments may have been contaminated by a high level of mesophylic, sporogenic,and asporogenic bacteria, hyphomycetes, and faecal coliforms. Also, the public health significance microorganisms such as Salmonella, Escherichia coli, Clostridium perfringens, Bacillus cereus, can be present. (Bendini et al., 1998). Since moist heat treatment is not generally suitable for such dry products, many commercial food processors fumigate spices and condiments with methyl bromide and ethylene oxide to eliminate insects or bacteria and moulds. Nowadays it has been appeared that, methyl bromide and ethylene oxide are high toxic compounds because of safety and environmental concerns. So, ethylene oxide has been banned in many countries and methyl bromide is being phased out globally (Marcotte, 2005). Based on the scientific evidence, irradiation of spices and condiments with a dose in the range of 5-10 kGy permits successful reduction of food-borne pathogens. The accurate dose applied would depend on the desired inactivation factor and the contamination (Farkas, 2006). Producers are now increasingly turning to ionizing radiation. Considering its antimicrobial activity and relatively minor effects on quality, irradiation is a feasible method for reducing the microbial load on spices and condiments (Sádecká et al., 2005). It is confirmed that the treatment with ionizing energy is more effective against bacteria than the thermal treatment and it is also less harmful to the spices than heat sterilization, which implicates the loss of thermo labile aromatic volatiles and/or causes additional thermally induced changes (e.g. thermal decomposition or production of thermally induced radicals). (Loaharanu, 1994; Olson, 1998; Alam Khan, 2010).

\subsection{Sea foods and fresh meats}

Several diseases originated by pathogenic Vibrios, Listeria monocytogenes, parasites and viruses are generally related to consumption of raw products (Venugopal, 2005). Irradiation of sea foods and fresh meats is proposed to extend shelf-life, inactivate parasites and decrease pathogen load (Norhana et al., 2010). Many studies indicated that irradiation at doses of $3 \mathrm{kGy}$, should yield 2 to $5 \log 10$ reduction of pathogenic, non spore forming bacteria (Guinebretiere et al., 2003; Lim et al., 2007). The applicable dose to fresh meats and sea foods should be adapted to the pathogen reduction and the product (O'Bryan et al., 2008; Norhana et al., 2010). For example, Shrimp is separate from fish and shellfish given that certain pathogens (i.e Listeria monocytogenes) for several log10 reductions need doses in excess of $3 \mathrm{kGy}$. In frozen shrimp the dose required to reduce Aeromonas hydrophila and Vibrio by 10-4 per gram was about $3 \mathrm{kGy}$, while $3.5 \mathrm{kGy}$ was needed for L. monocytogenes and 1.0 kGy for Salmonella (Hatha et al., 2003; Pinu et al., 2007). Irradiation of fresh meat 
can change colour, odour and taste. Some recent studies have shown, irradiation imparts undesirable organoleptic attributes to high-fat products. So, content of fat in the fresh meats and sea foods is a limiting factor (Norhana et al., 2010). These changes can be reduced by adapted atmosphere packaging and minimized fat levels and mainly prevented by irradiating in the frozen state. In frozen poultry products, the average dose of $7 \mathrm{kGy}$ would be adequate to provide at least a $5-\log 10$ reduction in the number of vegetative pathogens. There is no evidence that treatment by ionizing radiation made induce allergenicity. But, some studies showed that application of moderate radiation doses can make foods (which have some natural allergenic factors) less allergenic (EFSA, 2011). For instance, irradiation of eggs and products containing eggs has been used for the reduction of allergenicity and improving egg white foaming ability (Song et al., 2009).

\subsection{Other food classes/commodities}

Ready-to-eat foods are very various and their consumption has increased. These foods may cause a specific danger to consumers when they do not endure a process pathogen reduction (Sommers \& Boyd, 2006). To improve microbiological safety of ready-to-eat foods by irradiation, extensive research has been devoted, specifically to eliminate non sporeforming pathogens from ready-to-eat meat products. Irradiation is an effective treatment that can be used in many of these products after packaging (Romero et al., 2005). Also, Sommers and Boyd (2006) demonstrated that doses of 2 to 4 kGy inactivate food-borne pathogens including Salmonella spp., Listeria monocytogenes, Staphylococcus aureus, Escherichia coli O157:H7 and Yersinia enterocolitica in a variety of ready-to-eat food products.

Cheeses are also included in ready-to-eat foods. The pathogenic and toxin-producing microorganisms (considered in studies on irradiation of cheeses) are L. monocytogenes, pathogenic E. coli, Salmonella, Clostridium, Staphylococcus (mycotoxins), Brucella and Mycobacterium (Tsiotsias et al., 2002). The treatment of Camembert cheeses with gamma irradiation at doses up to $2.5 \mathrm{kGy}$ (from a health point of view) was acceptable (SCF, 2003). Tsiotsias et al. (2002) showed the feasibility of gamma irradiation at doses of 2-4 kGy for reducing L. monocytogenes inoculated into the freshly produced soft whey cheese. Also, JuWoon et al. (2005) studied irradiation of fried-frozen cheese balls and demonstrated that irradiation at dose of $3 \mathrm{kGy}$ is a successful treatment to make sure microbiological safety.

\subsection{Quarantine treatments}

The amount of transportation in all types of food product reaches millions of tons, annually. While world economic markets shrunk substantially, the cost of all traded agricultural products increased 19\% in 2008 (WTO, 2010). During transportation, some invasive species that may cause economic and environmental damage (especially in areas of the world where they do not currently exist) can be transmitted. However, plant pests are not only transported through agricultural goods; they can be found in any commodity. For instance, important tree-infesting beetles (Bostrichid beetles) have been transported in solid wood packing material and pallets arriving from other countries to U.S. states (Haack, 2006). A number of techniques have been investigated as quarantine treatments, and those most commonly used for commercial purposes involve extreme temperatures and fumigants (Heather \& Hallman, 2008; IPPC, 2009). Until the late 1920s, phytosanitary treatments were 
based on fumigation or nonsynthetic pesticide applications. The chemicals used then were largely not safe enough to be used on food but were used on nursery stock and other nonfood items that could carry invasive species. In 1929, nonchemical treatments (heated air and cold) were used as quarantine treatments against the fruit flies. The first international use of Phytosanitary irradiation was in December, 2004, when Australia sent one-half ton of irradiated mangoes to New Zealand. For a phytosanitary treatment to be commercially possible, the treated commodities must tolerate it. Most food products can tolerate radiation at the doses used for quarantine treatments (150 to $400 \mathrm{~Gy}$ ) and spice disinfection is the chief use of food irradiation worldwide today with over 185600 tons irradiated each year (Heather \& Hallman, 2008; Kume et al., 2009). Phytosanitary irradiation differs from other commercial treatments. The end point of the treatment is not acute mortality but it prevents further biological development and reproduction (Table 3).

\begin{tabular}{|c|c|c|c|c|c|c|c|}
\hline Treatment & End point & $\begin{array}{l}\text { Commodity } \\
\text { tolerance }\end{array}$ & Cost & $\begin{array}{l}\text { Certified } \\
\text { organic? }\end{array}$ & Speed & Logistics & $\begin{array}{l}\text { Commonly } \\
\text { treated } \\
\text { commodity }\end{array}$ \\
\hline Cold & Mortality & Moderate & Low & Yes & $\begin{array}{l}\text { Very } \\
\text { slow }\end{array}$ & Easy & $\begin{array}{l}\text { Citrus, } \\
\text { apple }\end{array}$ \\
\hline Heated air & Mortality & Moderate & Moderate & Yes & Moderate & Moderate & $\begin{array}{l}\text { Mango, } \\
\text { papaya }\end{array}$ \\
\hline $\begin{array}{l}\text { Hot water } \\
\text { immersion }\end{array}$ & Mortality & Moderate & Low & Yes & Fast & Moderate & Mango \\
\hline $\begin{array}{l}\text { Methyl } \\
\text { bromide } \\
\text { fumigation }\end{array}$ & Mortality & Moderate & Low & No & Fast & Easy & Citrus \\
\hline Irradiation & $\begin{array}{l}\text { Stop } \\
\text { development }\end{array}$ & High & Moderate & No & Fast & Moderate & $\begin{array}{l}\text { Mango, } \\
\text { guava }\end{array}$ \\
\hline
\end{tabular}

Table 3. Subjective comparison of major phytosanitary treatments (Hallman, 2011).

\section{Association with other preservation methods}

Irradiation in combination with other treatments may suppress the growth of surviving microorganisms during storage (Fan et al., 2006; Caillet et al., 2006). For example, the effect of irradiation was increased by packaging vegetables in atmospheres enriched with carbon dioxide or containing essential oils (Thayer \& Boyd, 1999). Sensory changes on high-fat products can be reduced by vacuum packaging associated to refrigeration and depend on the type of products (Zhu et al., 2009). Ahari et al. (2011) demonstrated that the combination of gamma irradiation and antagonist treatment (Pseudomonas fluorescens) was more effective in reducing Penicillium expansum growth, than either treatment alone and that integration of irradiation. Whereas, there is a dose rate limitation for application of gamma irradiation to control of postharvest disease on fruits and vegetables, the combination of irradiation and biocontrol agent increase applied range of irradiation for postharvest control by decreasing of dose rate (Ahari et al., 2011). Lee et al. (2005) demonstrated that the combined treatment of gamma irradiation and rosemary extract powder (genus Rosmarinus) improve the quality of a ready-to-eat hamburger steak by changing the storage condition from frozen $\left(-20^{\circ} \mathrm{C}\right)$ to a chilled temperature $\left(4^{\circ} \mathrm{C}\right)$. Fan et al. (2006) applied dose of $0.5 \mathrm{kGy}$ in combination with mild heat treatment for Shelf-life extension of fresh-cut cantaloupe. Also, Niemira et al. 
(2003) used freezing orange juice concentrates after irradiation, to reduction of Salmonella populations. The effect of irradiation on vegetables and sprouted seeds could be completed by washing with water (Rajkowski \& Fan, 2008). Chiasson et al. (2005) studied the effect of the combination of irradiation and different atmosphere conditions (CO2, air, MAP with $10 \% \mathrm{~N} 2,30 \% \mathrm{CO} 2$ and $60 \% \mathrm{O} 2$, and vacuum), a mix of tetrasodium pyrophosphate (TSP) and carvacrol on the reduction of E. coli and Salmonella typhi in minced beef.

\section{Packaging for irradiated foods}

The radiation treatment can be applied after packaging, so re-contamination or reinfestation of the products is avoided. In 2001, the FDA illustrated gamma rays, E-beam and $X$-ray to be equal in conditions of levels and types of radiolysis products formed in the packaging materials (Deeley, 2002; Goulash et al., 2004). Polymers such as polyethylene, polypropylene, poly vinyl chloride, polystyrene, polyethylene terepthalate and polyamide are some of the most common plastic packaging materials presently available. They all contain additives that vary in nature and quantity for obtaining certain useful properties. Some studies have shown, Irradiation can change some physical and chemical properties of polymeric packaging materials and the changes depend on the type of polymer, irradiation conditions and processing exposure (Ozen \& Floros, 2001; Hammad et al., 2006). For this reason any packaging materials must be confirmed by FDA before use in food irradiation (Crook \& Boylston, 2004; Pentimalli et al., 2000). Nowadays, flexible packages have been developed which tend to be multi-layer films with different barrier properties because, no single flexible material has all the chemical, physical and protective characteristics needed for packaging radiation-processed food (Chytiri et al., 2005; Twaroski et al., 2006).

\subsection{Physical effects}

Physical effects include changes in crystallinity, permeability, surface structures and post irradiation aging effects. Radiation changes in the physical properties of a packaging material should not delay its function (Han et al., 2004). Since the Permeability is measure of the ease with which gases or vapors can penetrate through the polymer materials, it is a major consideration in the selection of a polymeric material for food packaging (Han, 2007). Kale ( 1994) showed that, physical properties such as permeability, crystallinity, mechanical strength and IR spectra of irradiated polymers were unaffected at high doses carried out on the effect of radiation on polymeric films both single such as polypropylene, low density polyethylene (LDPE), PET and laminates (BOPP/LDPE, PET/LDPE, PET/PET/LDPE, PET/metalized PE/LDPE, PET/HDPE-LDPE, Polyolefin-Tie layer-Nylon-Tielayer-LDPE and 5 layer nylon coextruded film/Metalized PET). Study on different packaging films, permeating gases and analytical techniques have confirmed that, there is no modification in the permeability, crystallinity and shrinkage in regularly used packaging materials such as low density polyethylene (LDPE), high density polyethylene (HDPE), polypropylene, polyethylene terephthalate (PET), poly vinyl chloride and poly vinylidene chloride in the dose range of 0-8 kGy (Goulas et al., 2002). Some researches have shown that, changes in mechanical properties of certain polymers e.g. polyethylene can be minimized (when subjected to higher doses of radiation) using suitable stabilizers (Buchalla et al., 1997; Han, 2007). Also deterioration with respect to dosage was reduced after laminating of some polymers (e.g. polypropylene) with LDPE. 


\subsection{Chemical effects}

Most food packaging materials are originated from polymers. They may be susceptible to chemical changes (after ionizing radiation) that are the result of two reactions, cross-linking (polymerization) and chain scission (degradation). Both reactions are generally relative to dose, and depend on dose rate and the oxygen content of the atmosphere in which the polymer is irradiated (Ahn et al., 2003). Unique chemical markers present in irradiated packaging have not been recognized (Ahari et al., 2010). Chemical effects include evolution of radiolysis products, migration of radiolytic products of the polymers and degradation of antioxidants (Twaroski et al., 2006). Radiolytic degradation should neither be toxic nor affect the sensory qualities of the packed product. The vacuum condition or an inert atmosphere prevents radiation cross-linking of polymers. Also in the presence of oxygen (during irradiation of polymers) chain scission dominates. It is important because it has served as the basis for recent approvals under 21 CFR 170.39 (table 4) for packaging materials irradiated under non-oxygen atmospheres in contact with food (FDA, 2006a). During irradiation, ions and free radicals are produced. These highly reactive materials are responsible for the colour changes in irradiated polymers and could migrate into food and affect taste, odor and safety (Welle et al., 2002; Franz \& Welle, 2004; Stoffers et al., 2004). Also post irradiation aging effects could be the result of trapped radicals in crystalline regions of polymers (Buchalla et al., 1993a, 1993b). It must be noted that the radiationinduced changes depend on the polymer composition (additives), processing history of the plastic and the irradiation conditions (presence of oxygen, temperature, dose and dose rate). For example, plastic films containing a phenyl group or an amide linkage (are known to stabilize the polymer) are the most radiation resistant, due to their increased resonance energy (Variyar et al., 2000). Therefore, radiation resistant of polystyrene, polyester and polyamide is due to the high energy requirement to form cross-links (Crook \& Boylston, 2004).

\begin{tabular}{lll}
\hline 21 CFR Citation & Packaging Materials & Max Dose [kGy] \\
\hline & Nitrocellulose-coated cellophane & 10 \\
& Glassine paper & 10 \\
& Wax-coated paperboard & 10 \\
& Polyolefin film & 10 \\
Section 179.45(b) & Kraft paper & 0.5 \\
& Polyethylene terephthalate film (basic polymer) & 10 \\
& Polystyrene film & 10 \\
& Rubber hydrochloride film & 10 \\
& Vinylidene chloride-vinyl chloride copolymer film & 10 \\
& Nylon 11 [polyamide-11] & 10 \\
Section 179.45(c) & Ethylene-vinyl acetate copolymer & 30 \\
& Vegetable parchment & 60 \\
& Polyethylene film (basic polymer) & 60 \\
Section 179.45(d) & Polyethylene terephthalate film & 60 \\
& Nylon 6 [polyamide-6] & 60 \\
& Vinyl chloride-vinyl acetate copolymer film & 60 \\
\hline
\end{tabular}

Table 4. Packaging materials listed in 21 CFR 179.45 for use during irradiation of prepackaged foods (FDA, 2006a). 
Any new packaging material not yet listed in 21 CFR 179.45 is subject to a pre-market safety evaluation by FDA prior to irradiation. FDA (2006b) suggests that information be generated in accordance with the available guidance documents

(http://www.cfsan.fda.gov/ dms/guidance.html). Nowadays, most of the food packaging materials are normally resistant to doses used in food irradiation practice (EFSA, 2011).

\section{Irradiation facilities}

Ionizing radiation for food processing is limited to high energy photons (gamma rays) of radio nuclides ${ }^{60} \mathrm{Co}$ or ${ }^{137} \mathrm{Cs}$, $\mathrm{X}$-rays from machine sources with energies up to $5 \mathrm{MeV}$ and accelerated electrons with energies up to $10 \mathrm{MeV}$ generated by electron accelerating machines (Hvizdzak et al., 2010). These kinds of Ionizing radiation are preferred due to: i) the suitable food preservative effects; ii) do not generate radioactivity in foods or packaging materials; iii) available at costs as commercial use of the irradiation process (Farkas, 2004). The strength of the source and the length of time the food is exposed to the ionizing energy determine the irradiation dose, measured in grays (Gy) or kilo grays ( $1 \mathrm{kGy}=1,000 \mathrm{~Gy})$. One gray is equal with one joule of energy absorbed in a mass of one kilogram (EFSA, 2011).

\subsection{Gamma irradiation facilities}

Gamma rays with energies of 1.17 and $1.33 \mathrm{MeV}$ are emitted by the cobalt-60 or energy of $0.66 \mathrm{MeV}$ is emitted by caesium-137. The Co-60 is a radioactive metal that decays with a half-life of around 5.3 years. Although Cs-137 has a longer half-life of around 30.1 years, few commercial gamma facilities use Cs-137 as a gamma ray source. Because, Cs-137 emits gamma rays that are approximately half the energy of those emitted by Co-60 (Suresh et al., 2005). Gamma irradiation has higher penetration than Electron beams. Therefore, it is as suitable for treating large bulk packages of food. Gamma facilities are the majority of food irradiation facilities worldwide (Fig. 1). For instance, 27 of the 33 food irradiation facilities (23 in the EU) approved in 2010 are Co-60 gamma facilities and six are E-beam (EFSA, 2011). The gamma radiation can not be switched off and when not being used to treat food, must be stored in a water pool to absorb the radiation energy and protect workers from exposure if they must enter the irradiation room (Hvizdzak et al., 2010).

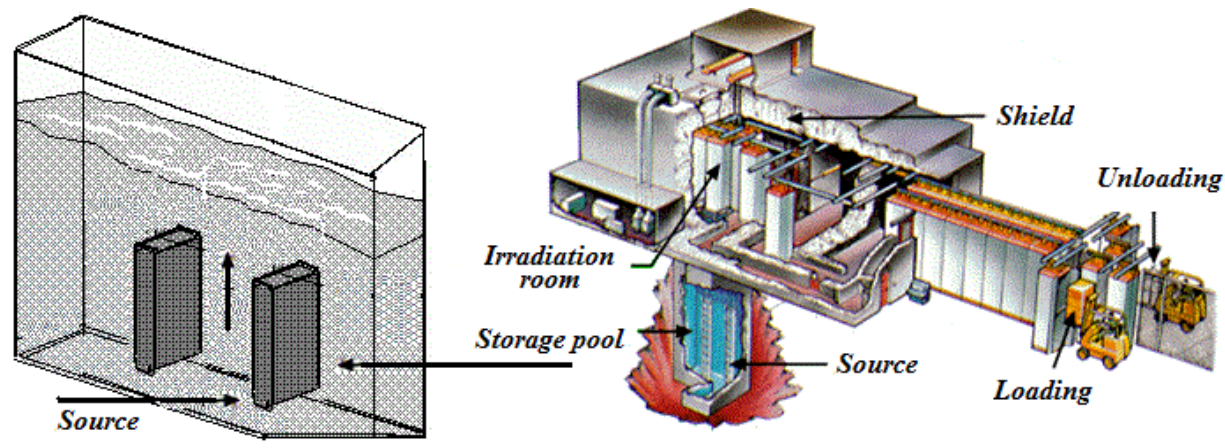

Fig. 1. Schematic diagram of a commercial gamma irradiator. The sealed sources are stored in water and raised into the air to irradiate a product that may be moved into the irradiation room on a conveyor system. 
It should be noted that, all radioactive irradiators must be licensed and meet all applicable safety requirements under the Atomic Energy Act of 1954. A license must be obtained from the Nuclear Regulation Commission (NRC) or an Agreement State prior to beginning construction of a new irradiator (NRC, 2009).

\subsection{E-beam facilities}

E-beams are produced by machines and not by radioactive material. They are generated by accelerating a stream of electrons, which are focused into a narrow beam-spot (Fig. 2b). As food is travels perpendicular to the beam direction, this spot of incident electrons is scanned across food (Suresh et al., 2005). E-beam radiation offers three distinct advantages compared with gamma: first, the need to carry radioactive materials around the country is eliminated. Second, it can be turned off when not in use and the last; E-beam characterized by its low penetration and high dosage rates. It performs best when used on low-density, uniformly packaged products. Therefore, it can effectively inactivate foodborne pathogens on the surface of the slices, with the least negative effect (Jeong-Ok et al., 2008; Hvizdzak et al., 2010).

\subsection{X-ray facilities}

X-rays are generated by machines and can be switched off. In this case, electrons are accelerated at a metallic target (e.g., tungsten or gold) to generate a stream of X-rays (Fig. 2a). In this process much of the E-beam energy is lost as heat; however the X-ray efficiency can be increased with atomic number of the target material and also with increasing E-beam energy (Kume et al., 2009). Nevertheless, X-ray facilities can process large bulk packages without the need for radioactive material. Nowadays, very few food products are irradiated by X-rays (Follett, 2004). As the technology advances, X-ray irradiation will become more extensive in future. But, it seems that, the commercial food irradiation facilities will continue to be gamma cells for a long period (Kume et al., 2009).

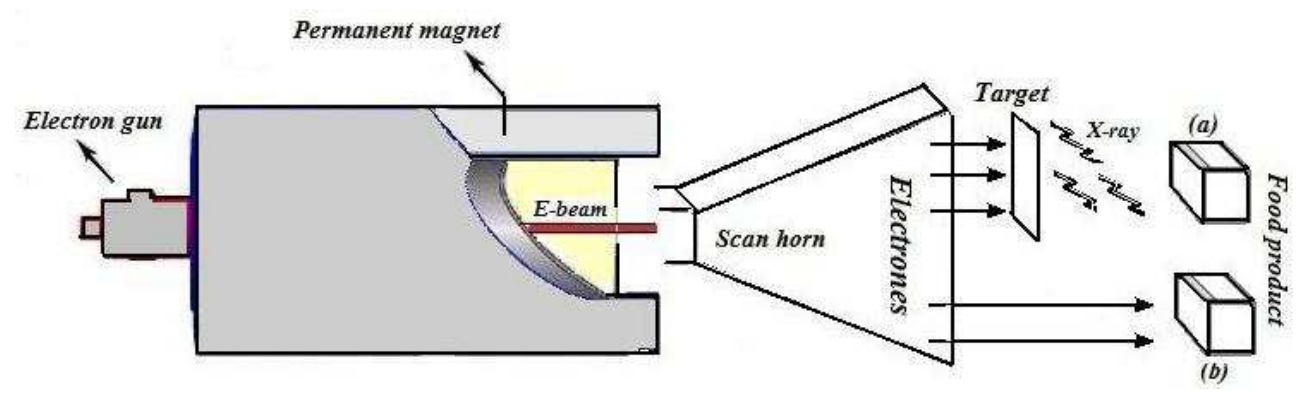

Fig. 2. Schematic diagram of a typical x-ray (a) and E-beam (b) irradiators

\section{General aspects of dosimetry}

Radiation dosimetry is the measurement of the absorbed dose in matter and products resulting from the exposure to radiation (Codex Alimentarius Commission [CAC], 2003). The estimated range of absorbed dose used in food processing is from 0.01 to $100 \mathrm{kGy}$. The irradiation dose absorbed by a product is not uniform due to the limits in penetration 
capacity of ionising radiations. This can reduce the overall efficacy of the food irradiation in practice (EFSA, 2011). It is necessary to determine the ability of an irradiation facility to deliver the absorbed dose, prior to the irradiation of the food product. Also, it is essential to monitor and document the absorbed dose during each production run (Moreno et al., 2008).

Dosimetry provides important functions in radiation processing, where large absorbed doses and dose rates have to be measured with practical accuracy. When dosimeters are exposed to radiation, they undergo a physical or chemical change in properties that can be recorded. This change is related to dose and dose rate, and it can be calibrated to a standard dose. For example, the basis of a common dosimetry system is plastic film containing a dye that changes color in proportion to dose. The color change can be calculated using a spectrophotometer and the degree color change can be calibrated to a dose standard. Verified dosimetry systems are extensively used to perform radiation measurements, quality control and validation of processes (Moreno et al., 2008).

The success of food irradiation depends on:

1. Calculations of the absorbed dose delivered to the food product;

In radiation processing, the absorbed dose is a key quantity in the processing of food. Therefore, dosimetry is a fundamental affair in radiation processing. Since the radiation absorbed dose is related to the desired effect in a particular food, the need for appropriate and precise dose measurement techniques must not be underestimated (IAEA, 2002). For instance, the dose received by every part of the product must be between Dmax (limit) and Dmin (Fig. 3).

2. Determination of the dose distribution patterns in the product package (process qualification);

Process load geometries are commonly limited to conventional shapes and sizes (e.g., rectangular cartons containing cylindrical, spherical or rectangular unit packages) of commercial food packaging. The importance of dosimetry in process qualification is to ensure that the absorbed dose requirements for a specific product can be satisfied. This process (dose mapping) verifies the scale and regions of the maximum and minimum doses (Fig. 3), and helps set up all the parameters required to achieve the absorbed dose (Mehta, 1992).

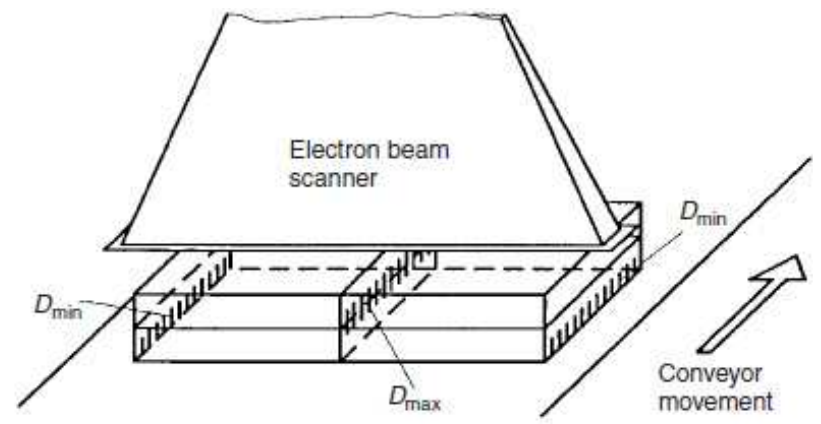

Fig. 3. Regions of Dmin and Dmax (indicated by hatching) for a rectangular process load for tow pass, tow sided electron beam irradiation (IAEA, 2002). 
3. Control of the routine radiation process (control procedures);

In order to ensure that the irradiation process is under control and the correct irradiation dose is being received by a specific product, routine dosimeters are used in radiation processing facilities. The routine dosimeters, traceable to national or international standards, are important and necessary in process control of food irradiation (Miller et al., 1989). Theses should be made during operation and records kept of such measurements can be used as supporting evidence (IAEA, 2002).

\section{Acceptance and trade}

The use of the treatment as a commercial food process depends on its acceptance by consumers. Frequently, consumers are conservative and they are reluctant to accept products processed by new technologies like as food irradiation method. This is often related to the fear and confusion about radiation itself and the lack of understanding of the process. The main worries of consumer organizations included safety, nutrition, detection, and labeling of irradiated products (P. Junqueira-Gonc-alves et al., 2011). The concern about the food irradiation appears to centre on the safety of the process. Giving science-based information on food irradiation leads to positive consumer approaches (Fox, 2002). Many consumers are primarily hostile to irradiation. By other means, "People think the irradiated product is radioactive," but when the process is made clear to them they will become more in favor (Landgraf et al. 2006; Marcotte, 2005). Fox (2002) reported that, consumer awareness of food irradiation was $29 \%$. Also, $80 \%$ of consumers were unsure about the safety of irradiated foods. Only $11 \%$ of the interviewers expressed that irradiated foods are safe. It should be noted that upon hearing a benefit statement of food irradiation, level of positive attitude increased significantly (62\%) towards irradiated foods. On the other hand, unfavorable description of irradiation has a great negative effect on consumer acceptance of irradiated foods. Recent study showed a low level of awareness among consumers about the food irradiation processing. $76.5 \%$ of the interviewed people did not know that irradiation could be used as a method for food preservation. $46 \%$ of them expressed that irradiated food means the same as radioactive food. Nevertheless, 91\% stated that if they knew that "irradiated" is not "radioactive" and that proper irradiation enhances food safety they would become consumers of irradiated food. $95.8 \%$ of the interviewers were not familiar with the "Radura" symbol (Fig. 4). However, 55.8\% of people expressed that they would buy irradiated food because of the Radura symbol (Junqueira-Gonc-alves et al., 2011). It shows that the labeling of irradiated products (the Radura symbol coupled with either "treated with ionizing radiation" or "irradiated") is the key issue with the consumers. Similar result was observed by Stephen et al. (2009). Because the words "radiation" and "irradiation" may have negative connotations, the labeling requirement has been viewed as an obstacle to consumer acceptance. Some researchers believe that an alternative wording, e.g. "electronically pasteurized," would be helpful (Morehouse \& Komolprasert, 2004). These results confirm the importance of training the public on the controversy, technology, and the benefits of irradiation.

Several countries have regulatory approvals in place for irradiation of one or more food products. But all these countries are not practically using the technology for a restricted number of food products (Johnson \& Reynolds, 2004; Marcotte, 2005). China, USA and Ukraine make up about three quarters of the whole food irradiated in the world. China is 
the most important country in the use of food irradiators. More than 200 facilities are reported from China and has about 100 irradiators with designed capacity of $>300 \mathrm{kCi}$ and more than 40 irradiators with designed capacity >1000 kCi. During 2006-2010 China established 20 new irradiators (EFSA, 2011). The number of radiation processing facilities and commercial food irradiation is showing an increasing trend around the world.

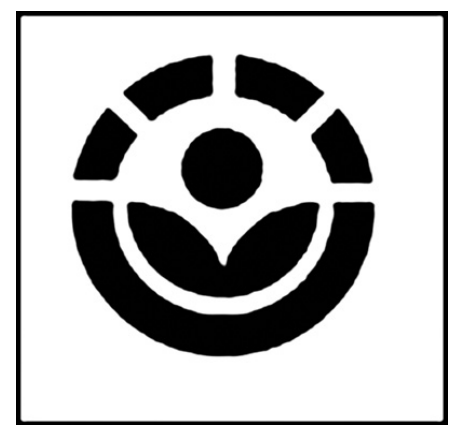

Fig. 4. The "Radura"symbol (in general it is presented in green color). The plant-like structure represents agricultural products in a closed package (the circle) broken in the upper half by penetrating ionizing rays or particles.

\section{Conclusions}

Food irradiation is approved for use in over 60 countries worldwide for different products, such as grains, herbs and spices, poultry, seafood, and ground beef (Kume et al. 2009). Irradiation does not cause any significant loss of macronutrients. Proteins, fats and carbohydrates undergo little modify in nutritional value through irradiation even with doses over $10 \mathrm{kGy}$, though there may be sensory changes. In the same way, the essential amino acids, essential fatty acids, minerals and trace elements are also unchanged. There can be a decrease in certain vitamins (mostly thiamin) but these are of the same order of magnitude as occurs in other manufacturing processes such as drying or canning (thermal sterilization) (Ahari et al., 2010). In the world today, 500000 tons of foods are irradiated every year among spices, meat, fresh fruits and vegetables. Despite the clear benefits of the food irradiation, this method remains under estimated in the food trade. It has not been commonly accepted and approved yet (Guy, 2011; Kume et al., 2009). The main factor in the way of commercial application of the food irradiation process is consumer acceptance. From our point of view, as consumer safety questions are discussed, food preservation throughout radiation contribution to food safety will reach the same recognition as the sterilization of medical products has in terms of preventing the spread infectious disease. For this reason, scientists have the responsibility to help the consumer understand the radiation process and it's potential to improve our lives and protect our health.

\section{References}

Ahari, M. H.; Fathollahi, H.; Motamedi, F. \& Mirmajlessi, S. M. (2010). Food irradiation: Applications, public acceptance and global trade: a review. African J. Biotech., Vol. 9, no. 20, pp. 2826-2833. 
Ahari, M. H.; Mirmajlessi, S. M.; Fathollahi, H.; Minasyan, V. \& Mirjalil S. M. (2011). Evaluation of gamma irradiation effect and Pseudomonas flourescens against Penicillium expansum, African J. Biotech., Vol. 10, no. 54, pp. 11290-11293.

Ahmed, M. (2001). Disinfestation of stored grain, pulses, dried fruits and nuts, and other dried foods, In: Molins, R. (ed.) Food Irradiation Principles and Applications, Wiley, New York, pp. 77-112.

Ahn, H. J.; Jo, C.; Lee, J. W.; Kim, J. H.; Kim, K. I. \& Byun, M. W. (2003). Irradiation and modified atmosphere packaging effects on residual nitrite, ascorbic acid, nitro-somyoglobin, and color in sausage, J. Agri. \& Food Chem., Vol. 51, pp. 1249-1253.

Alam Khan, K. \& Abrahem, M. (2010). Effect of irradiation on quality of spices. International Food Res. J., Vol. 17, pp. 825-836.

Arvanitoyannis, I. S.; Stratakos, A. C. \& Tsarouhas P. (2009). Irradiation applications in vegetables and fruits: a review. Critical Reviews in Food Science and Nutrition, Vol. 49, no. 5, pp. 427- 462.

Azelmat, K.; Sayah, F.; Mouhib, M.; Ghailani, N. \& Elgarrouj, D. (2005). Effects of gamma irradiation on forth-instar Plodia interpunctella (Hubner) (Lepidoptera: Pyralidae). J. Stored Prod. Res., Vol. 41, pp. 423-431.

Black, J.,L. \& Jaczynski, J. (2008). Effect of water activity on the inactivation kinetics of Escherichia coli O157: H7 by electron beam in ground beef, chicken breast meat, and trout fillets. Inter. J. Food Sc. \& Tech., Vol. 43, no. 4, pp. 579-586.

Boshra, S. A. \& Mikhaiel, A. A. (2006). Effect of gamma radiation on pupal stage of Ephestia calidella (Guenee). J. Stored Prod. Res., Vol. 42, pp. 457-467.

Brewer, M. S. (2009). Irradiation effects on meat flavor: a review, Meat Science, 1-14.

Buchalla, R.; Schuttler, C. \& Werner, B. (1993a). Effects of ionizing radiation on plastic food packaging materials, A review. Chemical and physical changes. J. Food Prot., Vol. 56, pp. 991.

Buchalla, R.; Schuttler, C. \& Werner, B. (1993b). Effects of ionizing radiation on plastic food packaging materials, A review. Global migration, sensory changes and the fate of additives. J. Food Prot., Vol. 56, pp. 998.

Buchalla, R.; Boess, C. \& Bogl, K. W. (1997). Radiolysis products in gamma-irradiated plastics by thermal desorption GC-MS, Part 1 Bundesinstitut fur Gesundheitlichen Verbraucherschutz und Veterinarmedizin, Berlin (BgVV-Hefte 04/1997).

Codex Alimentarius Commission (CAC), (2003). Report of the thirty fifth session of the codex committee on foot hygiene. Orlando, Florida, US., available at http://www.codexalimentarius.net/download/report/117/A10313ae.pdf

Caillet, S.; Millette, M.; Salmieri, S. \& Lacroix, M. (2006). Combined effects of antimicrobial coating, modified atmosphere packaging, and gamma irradiation on Listeria innocua present in ready-touse carrots (Daucus carota), J. Food Prot., Vol. 69, pp. 80-85.

Calucci, L.; Pinzino, C.; Zandomeneghi, M.; Capocchi, A.; Ghiringhelli, S.; Saviozzi, F.; Tozzi, S. \& Galleschi, L. (2003). Effects of gamma-irradiation on the free radical and antioxidant contents in nine aromatic herbs and spices, J. Agri. \& Food Chem., Vol. 51, pp. 927-934.

Chiasson, F.; Borsa, J. \& Lacroix, M. (2005). Combined effect of carvacrol and packaging conditions on radiosensitivity of Escherichia coli and Salmonella typhi in ground beef, J. Food Prot., Vol. 68, pp. 2567-2570.

Chytiri, S.; Goulash, A. E.; Badeka, A.; Riganakos, K. A. \& Kontominas, M. G. (2005). Volatile and non-volatile radiolysis products in irradiated multilayer coextruded food-packaging 
films containing a buried layer of recycled low-density polyethylene, Food additives \& contaminants, Vol. 22, pp. 1264-1273.

Crook, L. R. \& Boylston, T. D. (2004). Flavor characteristics of irradiated apple cider during storage: Effect of packaging materials and sorbate addition, J. Food Sci., Vol. 69, pp. 557-563.

Da Trindade, R. A.; Mancini, J \& Villavicencio, A. (2009). Effects of natural antioxidants on the lipid profile of electron beam-irradiated beef burgers, European J. Lipid Sci. and Tech., Vol. 111, pp. 1161-1168.

Deeley, C. (2002). Food irradiation: setting new standards or a slippery slope? Food Sci. Technol., Vol. 16, pp. 52-55.

De Wit, M. A.; Koopmans, M. P. \& Van Duynhoven, Y. T. (2003). Risk factors for novo virus, Sapporo-like virus and Group A rotavirus gastroenteritis, Emerging Infect. Dis., Vol. 9, no. 12 , pp. 163-170.

Diehl, J. F. (1995). Safety of irradiated foods, Marcel Dekker, Inc., New York, pp 1.

Dionísio, A. P.; Gomes, R. T. \& Oetterer, M. (2009). Ionizing radiation effects on food vitamins A Review. Brazilian Archives Biology Tech., Vol. 52, n. 5, pp. 1267-1278.

Dogan, A.; Siyakus, G. \& Severcan, F. (2007). FTIR spectroscopic characterization of irradiated hazelnut (Corylus avellana L.), Food Chem., Vol. 100, pp. 1106-1114.

Dong-Ho, K.; Hyun-Pa, S.; Hong-Sun, Y.; Young-Jin, C.; Yeung-Ji, K. \& Myung-Woo, B. (2002). Distribution of microflora in powdered raw grains and vegetables and improvement of hygienic quality by gamma irradiation, J. Korean Society Food Sci. \& Nutrition, Vol. 31, no. 4, pp. 589-593, Vol. 31, pp. 589-593.

Duliu, O. G.; Ferdes, M. \& Ferdes, O. S. (2004). EPR study of some irradiated food enzymes, J. Radioanalytical \& Nuclear Chem., Vol. 260, pp. 273-277.

EFSA (European Food Safety Authority), (2011). Statement summarizing the conclusions and recommendations from the opinions on the safety of irradiation of food adopted by the BIOHAZ and CEF panels, The EFSA J., Vol. 9, no. 4, pp. 2107.

Fan, X. (2003). Ionizing radiation induces formation of malondialdehyde, formaldehyde, and acetaldehyde from carbohydrates and organic acid, J. Agri. \& Food Chem., Vol. 51, pp. 5946-5949.

Fan, X. T. (2005). Formation of furan from carbohydrates and ascorbic acid following exposure to ionizing radiation and thermal processing, J. Agri. and \& Food Chem., Vol. 53, pp. 7826-7831.

Fan, X.; Annous, B. A.; Sokorai, K. J.; Burke, A. \& Mattheis, J. P. (2006). Combination of hotwater surface pasteurization of whole fruit and low-dose gamma irradiation of fresh-cut cantaloupe, J. Food Prot., Vol. 69, pp. 912-919.

Fan, X. T. \& Sommers, C. H. (2006). Effect of gamma radiation on furan formation in ready-to-eat products and their ingredients, J. Food Sci., Vol. 71, pp. C407-C412.

Fan, X. \& Thayer, D. W. (2002). Formation of malonaldehyde, formaldehyde, and acetaldehyde in apple juice induced by ionizing radiation, J. Food Sci., Vol. 67, pp. 25232528.

Farkas, J. (2004). Charged particle and photon interactions with matter, In: Mozumder, A. \& Hatano, Y. (eds): Food Irradiation, Marcel Dekker, New York, pp. 785-812.

Farkas, J. (2006). Irradiation for better foods, Trends in Food Sci. \& Tech., Vol. 17, pp. 148-152.

FDA (Food and Drug Administration), (2006a). http://www.cfsan.fda.gov/ dms/opatorx.html

FDA (Food and Drug Administration), (2006b). http://www.cfsan.fda.gov/ dms/opa2pmnc.html\#iid5. 
Follett, P. A. (2004). Irradiation to control insects in fruits and vegetables for export from Hawaii, Radiation Phys. \& Chem., Vol. 71, pp. 161-164.

Fox, J. A. (2002). Influences on purchase of irradiated foods. Food Tech., Vol. 56, no. 11, pp. 34-37.

Frankhauser, R. L.; Monroe, S. S. \& Noel, J. S. (2002). Epidemiologic and molecular trends of Norwalk-like viruses associated with outbreaks of gastroenteritis in the United State, J. Infect. Dis., Vol. 86, no. 1, pp. 1-7.

Galan, I.; Garcia, M. L. \& Selgas, M. D. (2010). Effects of irradiation on hamburgers enriched with folic acid, Meat Sci., Vol. 84, pp. 437-443.

Goetz, J. \& Weisser, H. (2002). Permeation of aroma compounds through plastic films under high pressure: in-situ measuring method, Innovative Food Sci. \& Emerg-ing Tech., Vol. 3, pp. 25-31.

Goulas, A. E.; Riganakos, K. A.; Badeka, A. \& Kontominas, M. G. (2002). Effect of ionizing radiation on the physic chemical and mechanical properties of commercial monolayer flexible plastics packaging materials, Food Additives Contaminants, Vol. 19, pp. 11901199.

Goulash, A. E.; Riganakos, K. A. \& Konotminas, M. G. (2004). Effect of ionizing radiation on physicochemical and mechanical properties of commercial monolayer and multilayer semirigid plastic packaging materials, Radiation phys. \& chem., Vol. 69, pp. 411-417.

Guinebretiere, M.H.; Girardin, H.; Dargaignaratz, C.; Carlin, F. \& Nguyen-The, C. (2003). Contamination flows of Bacillus cereus and spore-forming aerobic bacteria in a cooked, pasteurized and chilled zucchini puree processing line, International J. Food Microb., Vol. 82, no. 3, pp. 223-232.

Guinebretiere, M. H. \& Nguyen-The, C. (2003). Sources of Bacillus cereus contamination in a pasteurized zucchini puree processing line, differentiated by two PCR-based methods, Fems Microb. Ecology, Vol. 43, no. 2, pp. 207-215.

Guy, J. H. (2011). Phytosanitary Applications of Irradiation, Comprehensive Reviews in Food Sci. \& Food Safety. Vol. 10, no. 2, pp. 143-151.

Hallman, G. J. (2001). Irradiation as a quarantine treatment, pp. 113-130. In: R, Molins (ed). Food irradiation principles \& applications, Wiley-Int. sci., pp. 113-130.

Hallman, G. J. (2011). Phytosanitary Applications of Irradiation, Comprehensive Reviews in Food Science and Food Safety, vol. 10, no. 2, pp. 143-151.

Haack, R. A. (2006). Exotic bark- and wood-boring beetles in the United States: recent establishments and interceptions, Can. J. Res., Vol. 36, no. 2, pp. 269-88.

Hammad, A. A.; Abo-elnour, S. A. \& Salah, A. (2006). Use of irradiation to ensure hygienic quality of minimally processed vegetables and fruits, IAEA-TECDOC-1530. pp. 106-129.

Han, J.; Gomes-Feitosa, C. L.; Castell-Perez, E.; Moreira, R. G. \& Silva, P. F (2004). Quality of packaged romaine lettuce hearts exposed to low-dose electron beam irradiation, Lehensmittel Wissenschaft und Technologie, Vol. 37, pp. 705-715.

Hatha, A. A. M.; Maqbool, T. K. \& Kumar, S. S. (2003). Microbial quality of shrimp products of export trade produced from aquacultured shrimp, International J. Food Microb., Vol. 82, no. 3, pp. 213-221.

Heather, N. W. \& Hallman, G. J. (2008). Pest management and phytosanitary trade barriers. Wallingford, UK: CABI., p. 257.

Hendrichs, J. M.; Vreysen, J. B.; Enkerlin, W. R. \& Cayol. J. P. (2005). Strategic options in using sterile insects for area-wide integrated pest management, pp. 563-600 In Dyck, V. A.; Hendrichs, J. \& Robinson, A. S. [eds.], Sterile Insect Technique. Principles and 
Practice in Area-Wide Integrated Pest Management. Springer, Dordrecht, The Netherlands, 787 pp.

Hosseinzadeh, A. \& Shayesteh, N. (2011). Application of gamma radiation for controlling the red flour beetle Tribolium castaneum Herbst (Coleoptera: Tenebrionidae). African J. Agri. Res., Vol. 6, no. 16, pp. 3877-3882.

Hvizdzak, A. L.; Beamer, S.; Jaczynski, J. \& Matak, K. E. (2010). Use of Electron Beam Radiation for the Reduction of Salmonella enterica Serovars Typhimurium and Tennessee in Peanut Butter. J. Food Protec., Vol. 73, no. 2, pp. 353-357.

IAEA (International Atomic Energy Agency), (2001). Consumer acceptance and market development of irradiated food in Asia and the Pacific, Vienna, Austria, p. 98.

IAEA (International Atomic Energy Agency), (2002). Dosimetry for food irradiation, Vienna, Austria, p. 168.

IAEA (International Atomic Energy Agency), (2009). Irradiation to ensure the safety and quality of prepared meals, Vienna, Austria, p. 375.

International Plant Protection Convention (IPPC), (2009). Regulation of wood packaging material in international trade. Rome: Food and Agriculture Organization (FAO).

Jeong-Ok, L.; Seong, A. L.; Mi-Seon, K.; Hye-Rim, H.; Kyoung-Hee, K.; Jong-Pil, C. \& HongSun, Y. (2008). The effects of low-dose electron beam irradiation on quality characteristics of stored apricots. J. Korean Society Food Sci. \& Nutrition, Vol. 37, pp. 934-941.

Johnsson, L. \& Dutta, P. C. (2006). Determination of phytosterol oxides in some food products by using an optimized transesterification method, Food Chem., Vol. 97, pp. 606-613.

Johnson, M. \& Estes-Reynolds, A. (2004). Consumer Acceptance of Electron-Beam Irradiated Ready-to-Eat Poultry Meats, J. Food Process Preserv., Vol. 28, pp. 302-319.

Jung, H. H. (2007). Packaging for nonthermal processing of food. Chapter 5: Packaging for highpressure processing, irradiation, and pulsed electric field processing. Blackwell Pub. : IFT Press, pp. 67-86.

Junqueira-Gonc-alves, M. P.; Maria, J. G.; Ximena, V.; Carolina, M. D.; Paulina, A. \& Joseph, Miltz. (2011). Perception and view of consumers on food irradiation and the radura symbol, Radiation Physics \& Chem., Vol. 80, pp. 119-122.

Ju-Woon, L.; Jae-Hun, K.; Jang-Ho, K.; Sang-Hee, O.; Ji-Hyun, S.; Cheon-Jei, K.; Sung-Hee, C. \& Myung-Woo, B. (2005). Application of gamma irradiation for the microbiological safety of fried-frozen cheese ball, J. Korean Society of Food Sci. \& Nutrition, Vol. 34, pp. 729-733.

Kale, D. D. (1994). Effect of irradiation on polymeric packaging films, Report submitted to department of atomic energy, under board for research in nuclear sciences sponsored project, 1992-1994.

Kilcast, D. (1994). Effect of irradiation on vitamins, Food Chemi., Vol. 49, pp. 157-164. Kim, M. J.; Lee, J. W.; Seo, J. H.; Song, H. P.; Yook, H. S.; Choi, J. M. \& Byun, M. W, (2003). Safety evaluation on mutagenicity of white layer cake containing gamma irradiated egg white, J. Korean Society Food Sci. \& Nutrition, Vol. 32, pp. 1172-1173.

Klassen, W. \& Curtis. C. F. (2005). History of the sterile insect technique, pp. 3-36, In Dyck, V. A.; Hendrichs, J. \& Robinson, A. S. The Sterile Insect Technique: Principles and Practice in Area-Wide Integrated Pest Management. Springer, Dordrecht, The Netherlands, p. 787.

Koopmans, M. \& Duizer, E. (2004). Food borne viruses: an emerging problem, J. Food Microb., Vol. 90, pp. 23-24. 
Kottapalli, B.; Wolf-Hall, C. E. \& Schwarz, P. (2006). Effect of electron-beam irradiation on the safety and quality of Fusarium-infected malting barley, Int. J. Food Microb., Vol. 110, no. 3, pp. 224-231.

Kume, T.; Furuta, M.; Todoriki, S.; Uenoyama, N. \& Kobayashi, Y. (2009). Status of food irradiation in the world, Radiation Physics and Chemistry, Vol. 78, no. 3, pp. 222-226.

Landgraf, M.; Gaularte, L.; Martins, C.; Cestari, A.; Nunes, T.; Aragon, L.; Destro, M.; Behrens, J.; Vizeu, D. \& Hutzler, B. (2006). Use of irradiation to improve the microbiological safety of minimally processed fruits and vegetables, IAEA-TECDOC-1530, pp. 41-59.

Lee, J. W.; Park, K. S.; Kim, J. G.; Oh, S. H.; Lee, Y. S.; Kim, J. H. \& Byun, M. W. (2005). Combined effects of gamma irradiation and rosemary extract on the shelf-life of a ready-toeat hamburger teak. Radiation Physics \& Chem. Vol. 72, no. 1, pp. 49-56.

Levanduski, L. \& Jaczynski, J. (2008). Increased resistance of Escherichia coli O157: H7 to electron beam following repetitive irradiation at sub-lethal doses, International J. Food Microb., Vol. 121, no. 3, pp. 328-334.

Lim, S.; Jung, J. \& Kim, D. (2007). The effect of gamma radiation on the expression of the virulence genes of Salmonella Typhimurium and Vibrio spp, Radiation Physics \& Chem., Vol. 76, no. 11, pp. 1763-1766.

Loaharanu, P. (1994). Food irradiation in developing countries: a practical alternative, IAEA Bull., Vol. 1, pp. 30-35.

Lynch, M. F.; Tauxe, R. V. \& Hedberg, C. W. (2009). The growing burden of food borne outbreaks due to contaminated fresh produce: risks and opportunities, Epidemiology \& Infection, Vol. 137, no. 3, pp. 307-315.

Marcotte, M. (2005). Effect of irradiation on spices, herbs and seasonings-comparison with ethylene oxide fumigation, www.foodirradiation.com.

Mehta, K. (1992). Process qualification for electron-beam sterilization, Med. Device \& Diagnostic Ind., Vol. 14, no. 6, pp. 122-134.

Miller, R. D. (2005). Electronic irradiation of foods: an Introduction to the Technology, Springer. NY., p.295.

Miller, A. \& Chadwick, K. H. (1989). Dosimetry for the approval of food irradiation processes, Radiat. Phys. \& Chem., Vol. 34, pp. 999-1004.

Mitchell, G. E.; McLauchlan, R. L.; Isaacs, A. R.; Williams, D. J. \& Nottingham, S. M. (1992). Effect of low dose irradiation on composition of tropical fruits and vegetables. J. Food Comp. Anal., Vol. 5, pp. 291-311.

Morehouse, K. M. \& Komolprasert, V. (2004). Irradiation of Food and Packaging, An Overview, With Permission from ACS: ACS Symposium Series 875, Irradiation of Food and Packaging, chapter 1, pp. 1-11.

Moreno M. A.; Castell-Perez, M. E.; Gomes, C.; Da Silva P. F.; Kim, J.; \& Moreira, R. G. (2008). Treatment of cultivated high bush blueberries (Vaccinium corymbosum L.) with electron beam irradiation: Dosimetry and product quality, J. Food Process Engineering, Vol. 31, pp. 155-172.

Niemira, B. A.; Sommers, C. H. \& Fan, X. (2002). Suspending lettuce type influences recoverability and radiation sensitivity of Escherichia coli O157:H7, J. Food Prot., Vol. 65, pp. 1388-1393. 
Niemira, B. A.; Sommers, C. H. \& Boyd, G. (2003). Effect of freezing, irradiation, and frozen storage on survival of Salmonella in concentrated orange juice. J. Food Prot., Vol. 66, pp. 1916-1919.

Niemira, B. A. \& Lonczynski, K, A. (2006). Nalidixic acid resistance influences sensitivity to ionizing radiation among Salmonella isolates, J. Food Prot., Vol. 69, pp. 1587-1593.

Norhana, M. N. W.; Poole, S. E.; Deeth, H. C. \& Dykes, G. A. (2010). Prevalence, persistence and control of Salmonella and Listeria in shrimp and shrimp products: a review. Food Control, Vol. 21, no. 4, pp. 343-361.

NRC (Nuclear Regulation Commission), (2009). Fact sheet on commercial irradiators, Http//.www.nrc,gos/

Nunes, T, P.; Martins, C. G.; Behrens, J. H.; Souza, K. L. O.; Genovese, M. I.; Destro, M. T. \& Landgraf, M. (2008). Radioresistance of Salmonella species and Listeria monocytogenes on minimally processed arugula (Eruca sativa Mill.): Effect of irradiation on flavonoid content and acceptability of irradiated produce, J. Agri. \& Food Chem., Vol. 56, no. 4, pp. 12641268.

O'Bryan, C. A.; Crandall, P. G.; Ricke, S. C. \& Olson, D. G. (2008). Impact of irradiation on the safety and quality of poultry and meat products: A review, Critical Reviews in Food Sci. \& Nutrition, Vol. 48, pp. 442-457.

Ozen, B. F. \& Floros, J. D. (2001). Effects of emerging food processing techniques on the packaging materials. Trends in Food Sci. \& Technol., Vol. 12, no. 2, pp. 60-67.

Pentimalli, M. D.; Capitani, A.; Ferrando, D.; Fern, P.; Ragni, A. \& Segre, L. (2000). Gamma irradiation of food packaging materials: an NMR study, Polymer., Vol. 41, pp. 28712881.

Patterson, M.; Connoly, m. \& Darby, D. (2006). Effect of gamma irradiation on the microbiological quality of seeds and seeds sprouts. In use of irradiation to ensure the hygienic of fresh, precut fruits vegetables and other minimally processed food of plant origin, Vienna: International Atomic Energy, p. 536.

Pinu, F. R. Yeasmin, S.; Bar, M. L. \& Rahman, M. M. (2007). Microbiological conditions of frozen shrimp in different food market of Dhaka city, Food science and technology research, Vol. 13, no. 4, pp. 362-365.

Prakash, A.; Chen, P. C.; Pilling, R. L.; Johnson, N. \& Foley, D. (2007). 1\% calcium chloride treatment in combination with gamma irradiation improves microbial and physicochemical properties of diced tomatoes. Foodborne Pathog. Dis., Vol. 4, pp. 89-98.

Prendergast, D.M.; Crowley, K. M.; McDowell, D. A. \& Sheridan, J. J. (2009). Survival of Escherichia coli O157:H7 and non-pathogenic E. coli on irradiated and non-irradiated beef surfaces, Meat Sci., Vol. 83, no. 3, pp. 468-473.

Rajkowski, K. T. \& Fan, X. T. (2008). Microbial quality of fresh-cut iceberg lettuce washed in warm or cold water and irradiated in a modified atmosphere package, J. Food Safety, Vol. 28, pp. 248-260.

Romero, M. G.; Mendonca, A. F.; Ahn, D. U. \& Wesley, I. V. (2005). Influence of dietary vitamin $E$ on behavior of Listeria monocytogenes and color stability in ground turkey meat following electron beam irradiation, J. Food Prot., Vol. 68, pp. 1159-1164.

Sádecká, J.; Kolek, E.; Petka, J. \& Kovác, M. (2005). Impact of gamma-irradiation on microbial decontamination and organoleptic quality of oregano (Origanum vulgare L.). In: Proceedings of Euro Food Chem. XIII, Hamburg: pp. 590-594. 
SCF (Scientific Committee on Food), (2003). Revision of the opinion of the scientific committee on food on the irradiation of food, European commission health and consumer protection directorate general, SCF/CS/NF/IRR/24.

Scott Smith, J.; \& Suresh, P. (2004). Irradiation and food safety, Food tech., irradiation \& food safety. Vol. 58, no. 11, pp. 48-55.

Sommers, C. H. \& Boyd, G. (2006). Variations in the radiation sensitivity of foodborne pathogens associated with complex ready-to-eat food products. Radiation Physics \& Chem., Vol. 75, no. 7, pp. 773- 778 .

Song, H. P.; Kim, B.; Choe, J. H.; Jung, S.; Kim, K. S.; Kim, D. H. \& Jo, C. (2009). Improvement of foaming ability of egg white product by irradiation and its application, Radiation physics \& Chem., Vol. 78, no. 3, pp. 217-221.

Stefanova, R. Vasilev, N. V. \& Spassov, S. L. (2010). Irradiation of food, current legislation framework, and detection of irradiated foods, Food Analytical Methods, Vol. 3, pp. 225252.

Stephen, G. S. \& Downing-Matibag, T. (2009). Consumer acceptance of food irradiation: a test of the recreancy theorem. International J. Consumer Studies, Vol. 33, pp. 1470-6423.

Stewart, E. M. (2009). Effect of gamma irradiation on the quality of ready meals and their meat components. In: Irradiation to Ensure the Safety and Quality of Prepared Meals, Results of the coordinated research project organized by the joint FAO/IAEA division of nuclear techniques in food and agriculture (2002-2006). IAEA, Vienna, pp. 313-342.

Stoffers, N.; Linssen, H.; Josef, P. H.; Franz, R. \& Welle, F. (2004). Migration and sensory evaluation of irradiated polymers, Radiation Physics \& Chem., Vol. 71, no. 1, pp. 205208.

Suresh, P.; Leslie, A. \& Braby, L. (2005). Electron beam technology for food irradiation, The International Review of Food Science and Technology (Winter 2004/2005). An Official Publication of the International Union of Food Science and Technology (IUFoST).

Thayer, D. W. \& Boyd G. (1999). Irradiation and modified atmosphere packaging for the control of Listeria monosytogenes on turkey meat, J. Food Prot., Vol. 62, no. 10, pp. 1136-1142.

The Institute of Food Science and Technology (IFST), (2006). The use of irradiation for food quality and safety. info@ifst.org Web: www.ifst.org

Tomlins, K. (2008). Food safety and quality management, Food Africa. http://foodafrica.nri.org/safety/safetydiscussions1.html.

Tsiotsias, A.; Savvaidis, I.; Vassila, A.; Kontominas, M. \& Kotzekidou, R. (2002). Control of Listeria monocytogenes by low-dose irradiation in combination with refrigeration in the soft whey cheese' Anthotyros', Food Microb., Vol. 19, pp. 117-126.

Twaroski, M.; Bartaseh, L.; Layla, I. \& Bailey, A. B. (2006). The Regulation of Food Contact Substances in the United Sates, In Chemical Migration and Food Contact Materials, edited by Watson, D; Barnes, K. \& Sinclair, R., pp. 17-42. Cambridge, UK: Woodhead Publishing Limited.

Variyar, P. S.; Rao, B. Y. K.; Alur, M. D. \& Thomas, P. (2000). Effect of gamma irradiation on migration of additive in laminated flexible plastic pouches, J. Polym. Mater., Vol. 17, pp. 87-92.

Venugopal, V. (2005). Seafood processing: adding value through quick freezing, reportable packaging and cook-chilling and other methods, Venugopal, V. (ed), CRC Press, Taylor and Francis group, Boca Raton, FL., pp. 281-318. 
Vojdani, J. D.; Beuchat, L. R. \& Tauxe, R. V. (2008). Juice-associated outbreaks of human illness in the United States, 1995 through 2005. J. Food Prot., Vol. 71, no. 2, pp. 356-364.

Wang, Q. (2001). Effect of ionizing radiation on tensile properties of zein films, Food packaging of the Annual Meeting of IFT, New Orleans, Louisiana, USA.

Welle, F.; Mauer, A. and Franz, R. (2002). Migration and sensory changes of packaging materials caused by ionising radiation, Radiation Physics and Chem., Vol. 63, no. 3-6, pp. 841844.

World Health Organization (WHO), (2005). www.who.Int/media centre/fsctsheets/.

World Trade Organization (WTO), (2010). Available from: http://www.wto. org/english/res_e/statis_e/world_region_export_08_e.pdf.

Zhu, M. J.; Mendonca, A.; Ismail, H. A. \& Ahn, D. U. (2009). Fate of Listeria monocytogenes in ready-to-eat turkey breast rolls formulated with antimicrobials following electron-beam irradiation, Poultry Sci., Vol. 88, pp. 205-213. 


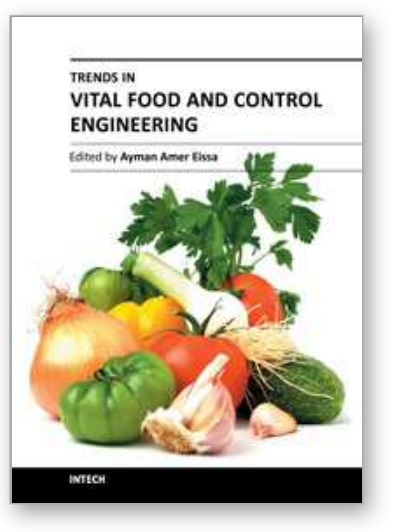

\author{
Trends in Vital Food and Control Engineering \\ Edited by Prof. Ayman Amer Eissa
}

ISBN 978-953-51-0449-0

Hard cover, 290 pages

Publisher InTech

Published online 05, April, 2012

Published in print edition April, 2012

This book is an example of a successful addition to the literature of bioengineering and processing control within the scientific world. The book is divided into twelve chapters covering: selected topics in food engineering, advances in food process engineering, food irradiation, food safety and quality, machine vision, control systems and economics processing. All chapters have been written by renowned professionals working in food engineering and related disciplines.

\title{
How to reference
}

In order to correctly reference this scholarly work, feel free to copy and paste the following:

Hossein Ahari Mostafavi, Seyed Mahyar Mirmajlessi and Hadi Fathollahi (2012). The Potential of Food Irradiation: Benefits and Limitations, Trends in Vital Food and Control Engineering, Prof. Ayman Amer Eissa (Ed.), ISBN: 978-953-51-0449-0, InTech, Available from: http://www.intechopen.com/books/trends-in-vitalfood-and-control-engineering/the-potential-of-food-irradiation-benifits-and-limitations

\section{INTECH}

open science | open minds

\author{
InTech Europe \\ University Campus STeP Ri \\ Slavka Krautzeka 83/A \\ 51000 Rijeka, Croatia \\ Phone: +385 (51) 770447 \\ Fax: +385 (51) 686166 \\ www.intechopen.com
}

\author{
InTech China \\ Unit 405, Office Block, Hotel Equatorial Shanghai \\ No.65, Yan An Road (West), Shanghai, 200040, China \\ 中国上海市延安西路65号上海国际贵都大饭店办公楼 405 单元 \\ Phone: +86-21-62489820 \\ Fax: $+86-21-62489821$
}


(C) 2012 The Author(s). Licensee IntechOpen. This is an open access article distributed under the terms of the Creative Commons Attribution 3.0 License, which permits unrestricted use, distribution, and reproduction in any medium, provided the original work is properly cited. 